\title{
Differential Responses of Hordeum vulgare L. to Allelochemicals of Some Olea europaea L.Cultivars
}

\author{
Salama M. El-Darier ${ }^{1}$, Amal M. Abdel-Rahman ${ }^{1} *$ and Tamannouha I. Saad ${ }^{2}$ \\ ${ }^{1}$ Botany and Microbiology Department, Faculty of Science, Alexandria University, Alexandria, Egypt \\ ${ }^{2}$ Botany Department, Faculty of Science, Omar Al-Mokhtar University, Libya
}

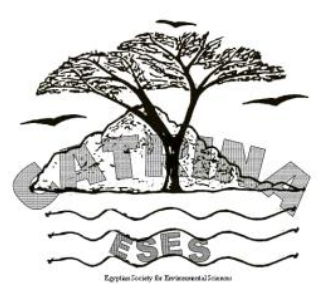

ABSTRACT
The present investigation was carried out to study the bioactivity of four Olea europaea cultivars (Chemlali; CHM, Manzanilla; MAZ, Picaul; PIC and Tofahi; TOF) leaves aqueous extract (OELAE) as well as crude powder (OELCP) on germination efficiency, physiological, biochemical and molecular parameters of Hordeum vulgare. The allelopathic effect varied according to treatment and cultivar. An increase in total seedling dry weight (TSDW) was achieved with all tested concentrations $(0.25,0.5,0.75$, $1,1.25$ and $1.5 \%$ ) of the four cultivars except TOF cultivar. Leaves of the donor species attained values of oleuropein varied from 35 to $67 \mathrm{mg} \mathrm{g}^{-1}$ dry weight depending upon the cultivar which was highly correlated with the level of antioxidants activity of germinated $H$. vulgare. Chlorophyll a (Chl a) recorded a marked increase with the increase in OELCP except for TOF. Noticeably, chlorophyll b (Chl b) and carotenoids (Carot) has shown a disturbance in their concentrations with both treatments and cultivars. The CHM (low oleuropein content) cultivar elicits high percentage of genomic template stability (GTS $\%$ ) in $H$. vulgare for the two-affecting concentration measuring about $86 \%$ and $82 \%$ respectively. To go through with this, TOF cultivar (high oleuropein content) achieved the lowest percentage of genomic template stability (GTS \%) in the two-affecting concentrations of about $36 \%$ and $32 \%$. Finally, we can conclude that if the growing barley is planting for herbal medicine purposes as antioxidant it prefers to be cultivated under CHM and MAZ olive trees and avoided cultivation under the two other cultivars; PIC and TOF.

Keywords: Allelopathy, germination efficiency, physiological, biochemical and molecular parameters, Hordeum vulgare, Olea europaea.

\section{INTRODUCTION}

Allelopathy is a biological phenomenon by which an organism produces one or more biochemicals that influences the germination, growth, survival, and reproduction of other organisms. Reigosa et al. (2006) considered the allelopathy as a physiological phenolmenon with ecological implications and considered as an applicable technique in plant ecology. Duke (2010) pointed to the beneficial effect of the biochemical released and the interaction between plants via compounds other than primary metabolites. Stamp (2003) considered these allelochemicals have either beneficial or detrimental effects on both the organism and environment and considered them as secondary metabolites which have role in plant-plant, plant-soil, plant disease, plant-insect and plant predator interactions (Tang et al., 1989). Rice (1984) defined the allelopathy has positive and negative effects and it was so broad that it covers almost all aspects of chemical ecology of plants. Several workers prefer to recognize only negative effects as allelopathic effects (Lambers et al., 1998) the plant contributing allelochemicals is recognized as the 'donor' plant, and the plant being influenced by the released allelochemicals is identified as the 'target' or 'afflicted' plant.

The allelopathic interaction can be one of the significant factors contributing to species distribution and abundance within plant communities (Zheng et al., 2015). This interaction plays an important role in crop productivity, conservation of genetic diversity, mainten- ance of ecosystems stability. These beside the strongly link with some environmental stresses (extreme temperature and radiation, nutrient deficit, insects, diseases and herbicides) and vegetation interaction in poly culture practices (Marzouk et al., 2017). Also, this interaction is a safe alternative use to endure developpment in sustainable agriculture and to leave a clean environment for future generations. It has a great potential to increase the productivity of field crops, vegetables, fruits trees, etc.

According to allelopathic effects on crops, this work has been done to examine the effect of the leaves of one of the economically important plants from which we obtain an important oil; olive (Olea europaea L.; Oleaceae) in the germination of barley grains. Olive is one of the most globally important long-lived Mediterranean fruit trees. In Egypt, there are many olive tree cultivars; however, among them the most common ones are Chemlali, Kalamata, Toffahi, Yonani, Aggezi, Shami, Hamed, Maraqi, Manzanilla, Picaul and Wattagen cultivars. Despite the socio-economic importance of olive tree cultivation and the health benefits of olive-derived products, studies addressing olive tree allelopathy in this region remain insufficient. El-Darier et al. (2018) pointed to the degree of expression of these biomolecules; allelochemicals depends on the presence and magnitude of them and they considered as biomarkers.

The aim of the present investigation was to validate whether the leaves of some Olea europaea cultivars (donor species) may contain different allelochemicals 
which interfere differentially with germination, seedling growth as well as some physiological, biochemical and molecular parameters of Hordeum vulgare (Poaceae, recipient species) associated as intercrop between olive trees.

\section{MATERIALS AND METHODS}

The present study was achieved to explore the effect of four olive cultivars namely; Chemlali; CHM, Manzanilla; MAZ, Picaul; PIC and Tofahi; TOF on seed germination and seedling growth of Hordeum vulgare. Leaves of the four O. europaea cultivars were collected from Burg El-Arab and Dabba regions (45 and $180 \mathrm{~km}$ west Alexandria, respectively) during the vegetative stage. Grains of $H$. vulgare were purchased from one of the most private seed stores (Shama) at Alexandria.

General phytochemical screening was carried out for leaves of the four cultivars according to the methods described by Harborne (1998), Marinova et al. (2005) and Singleton et al. (1999). Additionally, total flavornoids content was measured by a colorimetric assay (Kim et al., 2003). On the other hand, the content of oleuropein was performed by using the analytical HPLC system (Boligon and Athayde, 2014).

Leaves collected from the studied cultivars were dried in shade for 15 days thereafter, ground in a Wiley Mill to coarse uniform texture. Different extract concentrations $(0.25,0.5,0.75,1,1.25$ and $1.5 \%)$ and distilled water as a control were prepared. The procedures were performed according to El-Rokiek et al. (2010) and Algandaby et al. (2014).

Germination bioassay experiment was applied to investigate the potential allelopathic effects of $O$. europaea leaves aqueous extract from the four studied cultivars on germination percentages (GP) of recipient species.To achieve this experiment, ten grains of $H$. vulgare were arranged in 9-cm diameter Petri-dishes lined with two discs of Whatman No.1 filter paper under normal laboratory conditions with day temperature ranging $25-30^{\circ} \mathrm{C}$ and night temperature ranging 20 $25^{\circ} \mathrm{C}$. Ten $\mathrm{ml}$ of the respective donor species aqueous extracts or distilled water were added daily to three replicates in a randomized complete block design. Before sowing, grains were immersed in $2 \%$ CHLOREX for $2 \mathrm{~min}$ then rinsed four times with distilled water. Finally, grains were soaked in aerated distilled water for $24 \mathrm{hr}$.

Germination percentage (GP) of $H$. vulgare was expressed as a percentage of growth (germination) in different concentrations with respect to control (distilled water). Higher values indicate lower toxicity.

Germination percentage $=$ (Number of germinated grains/total number of grains) X 100

For growth bioassay, six soil samples from the natural sites where the alleged materials allelopathic are not deposited were used to execute the growth experiment. The $H$. vulgare grains were selected uniformity of size, shape and color. Prior to germination, grains were surface sterilized by soaking for $2 \mathrm{~min}$ in $2 \%$ CHLOREX, then washed several times with distilled water. Finally, grains were soaked in aerated distilled water for $24 \mathrm{hr}$.

The experiment was performed to verify the effect of different levels for the four cultivars of O.europaea leaves crude powder mixed (w/w) with sandy loam soils on some growth and physiological parameters as well as protein profile of the recipient species. To achieve this experiment, ten grains from the recipient species were sown in plastic pots $(15 \mathrm{~cm}$ in diameter and $14 \mathrm{~cm}$ height) thoroughly mixed $(\mathrm{w} / \mathrm{w})$ with 900 -gram soil under different concentrations $(0.5,1,1.5$ and $2 \%)$ of crude powder of the donor species. The experiment was performed under normal laboratory conditions $\left(24-25^{\circ} \mathrm{C}\right.$ day temperature, $19-21^{\circ} \mathrm{C}$ night). One treatment was run as a control with zero percent of crude powder. The pots were irrigated every two days with distilled water according to the amount calculated from the field capacity. After 21days, five healthy homogenous seedlings were carefully harvested from each treatment, washed with tap water to remove the adhered soil particles then by distilled water and gently swathed with filter paper. Seedling dry weight $(\mathrm{mg})$, seedling length (cm) and leaf area $\left(\mathrm{cm}^{2}\right)$ was calculated according to Cain and Castro (1959).

Determination of some physiological parameters such as chlorophyll a, b (chl. a, chl. b) and carotenoids (carot) were determined according to Inskeep and Bloom (1985) while carotenoids were estimated according to Lichtenthaler (1987).The antioxidant activity was evaluated by using the stable 2, 2-diphenyllpicrylhydrazyl radical (DPPH) according to a modification of the method described by Bandoniene et al. (2002).

Sodium dodecyl sulphate polyacrylamide gel electrophoresis (SDS-PAGE) was applied (Laemmli, 1970) for assessing the allopathic effect of $O$. europaea leaves crude powder (OELCP) related to four cultivars at $0.5,1,1.5$ and $2 \%$ concentration on protein content and its banding pattern of the studied recipient seedlings species according to Laemmli (1970). The bands produced by each sample were counted and the percentage of polymorphism was determined according to (Cimino, 2006).

All the data of the present study were subjected where appropriate to standard two-way analysis of variance (ANOVA) (Kirkpatrick and Feeney, 2013).

\section{RESULTS}

The phytochemical screening of the four olive cultivars is presented in tables (1,2 and 3). Data in table (1) showed that, the donor species was found to contain alkaloids, flavonoids, glycosides, phenols and oleuropein. In addition, the data clearly demonstrate that, the total flavonoids in Chemlali, Manzanilla, Picaul and Toffahi cultivars were $72.74 \pm 2.00,105.46 \pm 3.00$, $134.03 \pm 2.45$ and $156.05 \pm 1.20 / \mathrm{mg} \mathrm{CE} \mathrm{g}^{-1}$ respectively. Respecting total phenols, the values were $78.71 \pm 1.92,90.20 \pm 2.67,106.30 \pm 2.06$ and $153.05 \pm 1.88 / \mathrm{mg}$ GAE $\mathrm{g}^{-1}$ respectively. Similarly, oleuropein attained values of $35.02 \pm 1.95,47.24 \pm 2.05$, 
Table (1): Total phenols and total flavonoids as well as oleuropein content in four Olea europaea cultivars leaf extracts. Data are means of three replicates \pm SD.

\begin{tabular}{lccc}
\hline \hline Cultivar & $\begin{array}{c}\text { Total Flavonoids } \\
\text { (mg CE } \text { g }^{-1} \mathbf{d r y} \\
\text { weight) }\end{array}$ & $\begin{array}{c}\text { Total Phenols (mg } \\
\text { GAE } \text { g }^{-1} \text { dry weight) }\end{array}$ & $\begin{array}{c}\text { Oleuropein } \\
\text { (mg g-1 dry weight) }\end{array}$ \\
\hline Chemlali & $72.74 \pm 2.00$ & $78.71 \pm 1.92$ & $35.02 \pm 1.59$ \\
Manzanilla & $105.64 \pm 3.00$ & $90.20 \pm 2.67$ & $47.24 \pm 2.05$ \\
Picaul & $134.03 \pm 2.45$ & $106.30 \pm 2.06$ & $55.42 \pm 1.41$ \\
Toffahi & $156.05 \pm 1.20$ & $153.05 \pm 1.88$ & $67.76 \pm 0.64$ \\
\hline \hline
\end{tabular}

Table (2): Flavonoids and phenolic compounds $\left(\mathrm{mg} \mathrm{g}^{-1} \mathrm{dw}\right)$ identified in the methanolic extract in the dried leaves of four Olea europaea cultivars.

\begin{tabular}{lllll}
\hline \hline \multicolumn{1}{c}{ Compound } & \multicolumn{5}{c}{ Cultivar } \\
\cline { 2 - 5 } & Chemlali & Manzanilla & Picaul & Toffahi \\
\hline Flavonoids & 3.00 & 3.44 & 4.10 & 5.242 \\
Rutin & 1.23 & 2.10 & 2.60 & 3.19 \\
Hesperetin & 0.70 & 1.01 & 1.994 & 2.40 \\
Quercetin & 0.015 & 0.025 & 0.034 & 0.055 \\
Kampferol & - & 0.150 & 0.190 & 0.223 \\
Apigenin & & & & \\
Phenolic compounds & 0.036 & 0.045 & 0.078 & 0.087 \\
Gallic acid & 0.220 & 0.290 & 0.327 & 0.327 \\
Protocatechuic acid & 0.254 & - & 0.388 & 0.490 \\
Catechin & 0.521 & 0.612 & 0.700 & 0.721 \\
Chlorogenic acid & 1.053 & 0.931 & 1.221 & 1.941 \\
Catechol & 0.300 & 0.340 & 0.535 & 0.541 \\
Caffein & 0.060 & 0.060 & 0.081 & 0.071 \\
Vanillic acid & 0.200 & 0.200 & 0.222 & 0.213 \\
Ferulic acid & 0.650 & 0.670 & 0.680 & 0.770 \\
Salycilic acid & 2.000 & 2.220 & 3.000 & 3.210 \\
Benzoic acid & 1.115 & 1.118 & 1.157 & 1.312 \\
Coumarin & 0.038 & 0.040 & 0.048 & 0.060 \\
Chrysin & &
\end{tabular}

Additionally, Table (2) illustrates that, Toffahi cultivar attained the highest concentrations of all individuals of flavonoids and phenolic compounds except Vanillic and ferulic acids which attained their maxima in Picaul cultivar.

The corresponding allelopathic effects of the four $O$. europaea cultivars aqueous extracts on germination percentage (GP) of $H$. vulgare were documented (Fig. 1). Data confirm that, the GP decreased significantly upon applying different concentrations of the four extracts and the decrease was most prominent in PIC compared with the other three cultivars. The reduction percentages in GP at the maximum extract concentration were $42.84,57.14,71.42$ and $57.14 \%$ compared with the control for CHM, MAZ, PIC and TOF respectively. It was remarkable that lower extract concentrations $(0.25 \%)$ for all cultivars except CHM elicit stimulation effect for the process of seed germination. Data was statistically significant at $(p \leq 0.05)$ as evaluated by Two-way ANOVA test. Total seedling dry weight increases and the maximum increase was 50, 117.5 and $92 \%$ for CHM, MAZ and PIC at 1, 1.5 and 2 $\%$ concentration level respectively compared to the control. With respect to TOF all concentrations achieved $50 \%$ increase except $1.5 \%$ concentration level.

Generally, the variation in total seedling lengths (TSL) was not significant respecting the two studied factors (concentration $\mathrm{X}$ cultivar) except for the lower concentrations which achieved a stimulation effects. The variation in leaf area (LA) was not significant respecting the concentration factor for all cultivars.
Otherwise, the cultivars showed significant variations especially in $1 \%$ level as calculated by Two-way ANOVA.

A corresponding allelopathic effect of the different concentrations of four $O$. europaea cultivars on photosynthetic pigments of $H$. vulgare was recorded (Fig. 2). Considerable increase in the concentration (mg $\mathrm{g}^{-1} \mathrm{fw}$ ) of $\mathrm{Chl}$ a, it was progressed with the increase in concentrations levels especially at $2 \%$ except for TOF where the maximum increase was attained at $1.5 \%$ concentration level. On the other hand, Chl a concentration in the four cultivars was significantly differed as evaluated by Two-way ANOVA. The Chl. b ( $\mathrm{mg} \mathrm{g}^{-1} \mathrm{fw}$ ) in CHM was stimulated at $0.5 \%$ concentration level relative to control. The maximum for MAZ was attained at the maximum concentration $(2 \%)$. The concentration ranges from 0.5 to $1.5 \%$ attained the higher concentrations for $\mathrm{Chl} \mathrm{b}$ regarding PIC cultivar. The last cultivar (TOF) showed its minimum and maximum concentrations at 1 and $1.5 \%$ respectively. Furthermore, the four cultivars were differed significantly as evaluated with Two-way ANOVA. Generally, the four cultivars exhibited a significant difference in Carot. Concentration ( $\mathrm{mg} \mathrm{g}^{-1} \mathrm{fw}$ ) respecting the two factors (concentration $\mathrm{x}$ cultivar). Carot. Recorded the lowest value (about $0.13 \mathrm{mg} \mathrm{g}^{-1} \mathrm{fw}$ ) at concentration $0.50 \%$ in CHM compared with the control $\left(1.72 \mathrm{mg} \mathrm{g}^{-1} \mathrm{fw}\right)$, while the highest values (3.60 mg g $\left.\mathrm{g}^{-1} \mathrm{f} . \mathrm{w}\right)$ were recorded at concentration $2 \%$ for PIC. As well at concentration $1 \%$ in TOF attained the higher concentration (about $3.13 \mathrm{mg}$ $\mathrm{g}^{-1} \mathrm{fw}$ ) of Carot. 


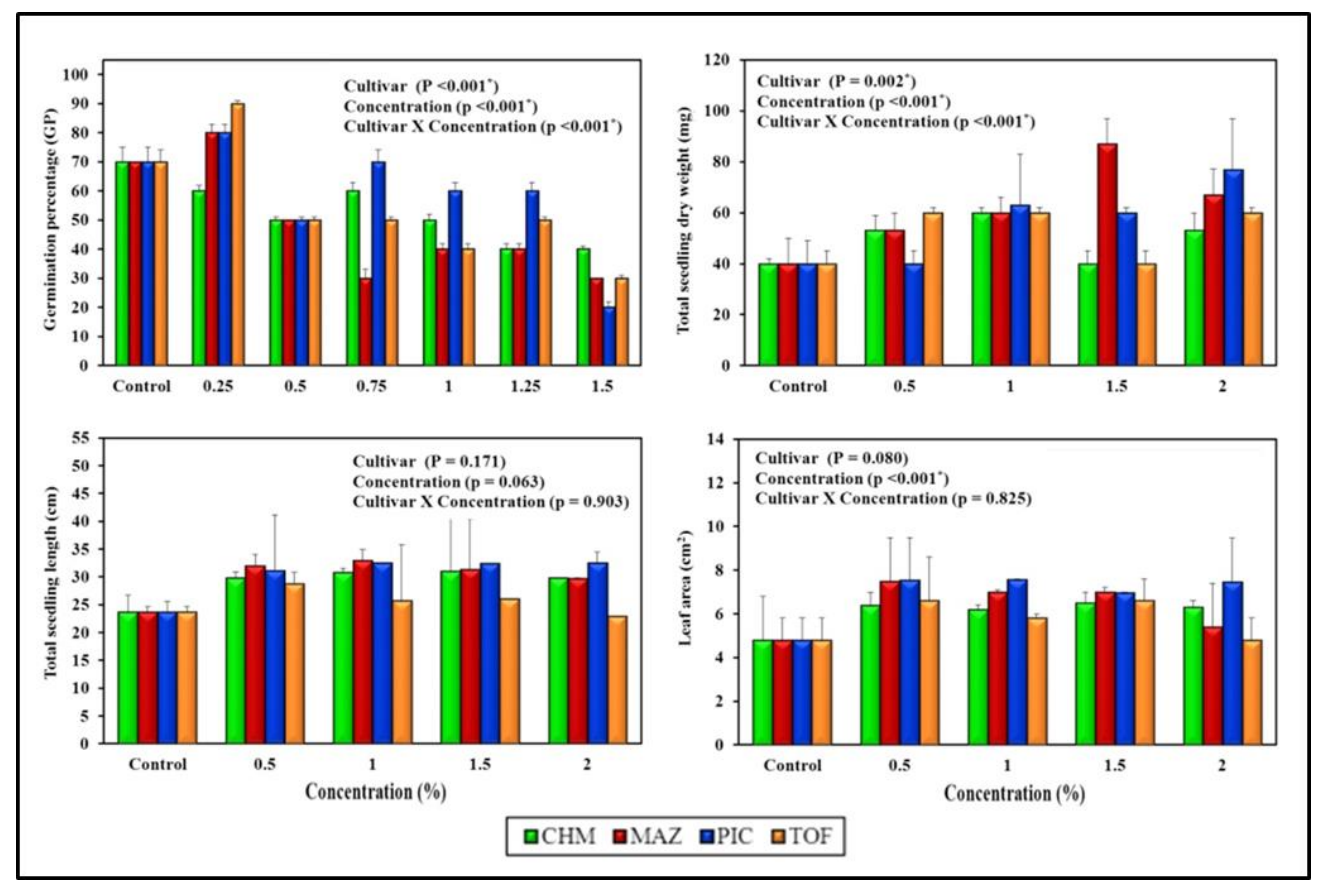

Figure (1): Variation in the different germination and growth parameters (Mean \pm SD) as well as results of Two-way ANOVA of Hordeum vulgare as affected by different concentrations (\%) of four Olea europaea cultivars (Chemlali,CHM; Manzanilla, MAZ; Picaul, PIC and Toffahi, TOF) leaf extract (OELAE) and crude powder (OELCP).

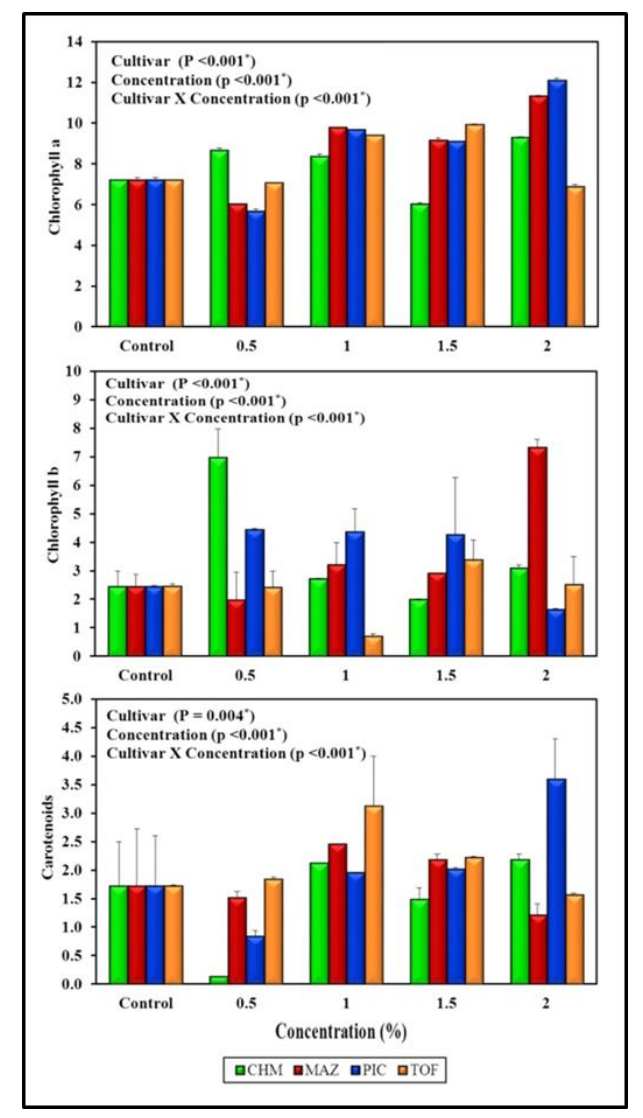

Figure (2): Variation in photosynthetic pigments ( $\mathrm{Chl} \mathrm{a}$, Chl b and Carot) ( $\mathrm{mg} \mathrm{g}^{-1} \mathrm{fw}$ ) of Hordeum vulgare at 21-days after sowing as affected by different concentrations (\%) of leaf crude powder (OELCP) offour Olea europaea cultivars (Chemlali,CHM; Manzanilla, MAZ; Picaul, PIC and Toffahi, TOF) Data are mean \pm SD. LSD was calculated at $\mathrm{p}<0.001$. 
Antioxidant activity (Ant.) demonstrates that, there was an increase in antioxidant activity with the increase in concentration level compared to control for cultivars CHM and MAZ (Fig. 3). The values of antioxidant activity for the two cultivars were nearly the same and non-significantly affected with the concentration levels. Concerning PIC and TOF, there have been no apparent differences in the antioxidant values compared to the control. Nevertheless, the variation in antioxidant was significant among the four cultivars.

Protein electrophoresis was carried out to evaluate influence of CHM, MZA, PIC and TOF Olea europaea leaf crude powder (OELCP) on Hordeum vulgare at 0.5 and $2 \%$ concentration levels relative to control (Plate 1 and Table 3).

Data concerning to total number of bands, percentage of polymorphism and genomic template stability (GTS $\%$ ) of the four cultivars are illustrated in table (3).

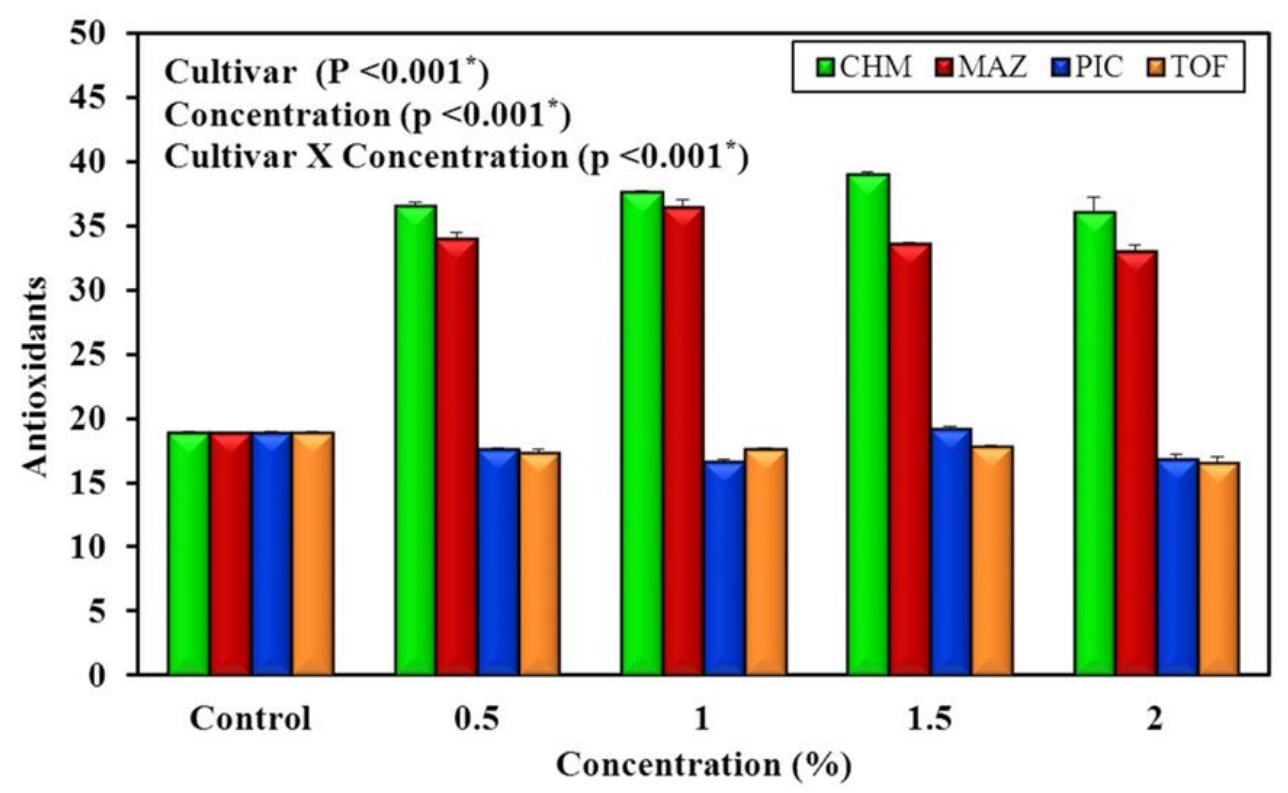

Figure (3): Variations in antioxidant activity of Hordeum vulgareat21-days after sowing as affected by different concentrations (\%) of leaf crude powder (OELCP) of our Olea europaea cultivars (Chemlali,CHM; Manzanilla, MAZ; Picaul, PIC and Toffahi, TOF). Data are means \pm SD. LSD was calculated at $p<0.001$

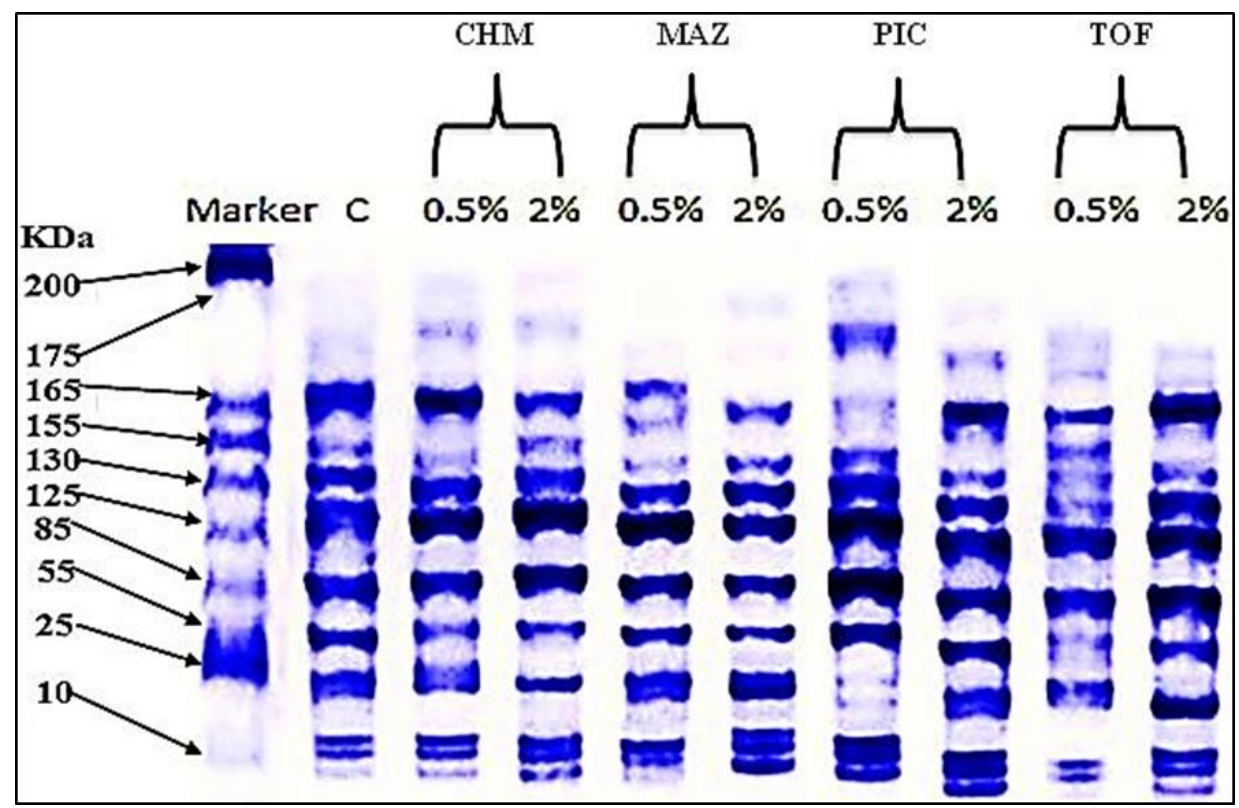

Plate (1): Seedling protein electrophoresis attained from the seedling of CHM, MZA, PIC and TOF cultivars of Hordeum vulgare affected by $0.5 \%$ and $2 \%$ concentration of Olea europaea L. leaf crude powder (OELCP). 
Table (3): Details of the seedling protein patterns for the studied species Chemlali (CHM), Manzanilla (MZA), Picaul (PIC) and Toffahi (TOF) cultivars of Hordeum vulgare affected by $0.5 \%$ and $2 \%$ concentration of Olea europaea $\mathrm{L}$. leaf crude powder (OELCP).

\begin{tabular}{|c|c|c|c|c|c|c|c|c|c|}
\hline \multirow{4}{*}{ Characters } & \multirow{4}{*}{ Control } & \multicolumn{8}{|c|}{ Cultivars } \\
\hline & & \multicolumn{2}{|c|}{$\begin{array}{c}\text { Chemlali } \\
\text { (CHM) }\end{array}$} & \multicolumn{2}{|c|}{$\begin{array}{c}\text { Manzanilla } \\
\text { (MZA) }\end{array}$} & \multicolumn{2}{|c|}{$\begin{array}{c}\text { Picaul } \\
\text { (PIC) }\end{array}$} & \multicolumn{2}{|c|}{ Toffahi (TOF) } \\
\hline & & \multicolumn{8}{|c|}{ Concentration( $\%)$} \\
\hline & & $0.5 \%$ & $2 \%$ & $0.5 \%$ & $2 \%$ & $0.5 \%$ & $2 \%$ & $0.5 \%$ & $2 \%$ \\
\hline Total number of bands & 11 & 10 & 11 & 9 & 10 & 13 & 13 & 13 & 12 \\
\hline Percentage of polymorphism (\%) & 41 & 37 & 41 & 32 & 37 & 51 & 51 & 50 & 46 \\
\hline Genomic Template Stability (GTS \%) & 100 & 86 & 82 & 82 & 68 & 59 & 41 & 36 & 32 \\
\hline
\end{tabular}

At 0.5 concentration level of MAZ cultivar achieved the minimum values ( 9 bands and $32 \%$ ) for both the number of bands and the percentage of polymorphism respectively, while the maximum values (13bands and $51 \%$ ) were achieved by PIC cultivar at 0.5 and $2 \%$ concentration level respectively. The genomic template stability (GTS\%) oscillated from $32 \%$ in TOF cultivar at $2 \%$ concentration levels to $86 \%$ in $\mathrm{CHM}$ cultivar at $0.5 \%$ concentration levels.

\section{DISCUSSION}

The Economic Affairs Sector of the Egyptian Ministry of Agriculture reported that the cultivated area of Olea europaea in the year 2000 was 108.3 thousand feddans. Additionally, the productive area and the average production of feddan were 73.3 thousand feddan and 3.8 tones per feddan respectively. The total production was 281.7 thousand tons about 27,000 tons of fruits are used to extract about 4,000 tons of oil. The cultivated area of the world is 9 million hectares, producing about 10 million tons of fruits, of which one million tons are used as table olives and the rest for the extraction of about 2 million tons of oil. Most of the production is consumed by the producing countries (Mohamed and Saad El-Din, 2002).

Nowadays, there is a large move from monocropping to polycropping practices, in almost of the agricultural ecosystems along the world. One should be aware by the chemical interfering between the mixed crops in order to avoid undesirable potential effects of one crop on the other (Al-Hussaini, 2013). Multiple cropping is commonly practiced by Bedouins in the western coastal region of Egypt such as crop rotation, sequential cropping, mixed and strip cropping and multi-storied cropping. Past information estimated the cultivation of field crops and vegetables between Ficus carica, Olea europaea, Vitis vinifera, Prunes amygdalus and other fruit trees in the region (Gajam, 2016).

Allelopathy is direct and indirect plant interactions mediated by allelochemicals (Cheema et al., 2013). When plants are exposed to allelochemicals, their growth and development are highly affected (Niakan $e t$ al., 2008). Allelochemicals significantly interfered with germination and growth, some physiological parameters, chemical constituents and protein expression of the recipient species. This interference took place either by stimulation or suppression (Sunar et al., 2013).
The allelopathic potential of OELAE (as donor species) of four olive cultivars (CHM, MAZ, PIC and TOF) at different concentrations levels $(0.25,0.50,0.75,1,1.25$ and 1.50 relative to control) on grain germination of Hordeum vulgare (as a recipient species) was confirmed.

Germination bioassay in the present study indicated that the inhibitory effect varied with measured parameter, cultivar and extract concentration, whereas in some cases the study registered a stimulatory effect. Noteworthy, the minimum concentration of the extract $(0.25 \%)$ for all O. europaea cultivars other than CHM cause stimulation affect for the process of grain germination. The stimulatory allelopathic effects of any plant can be used to develop ecofriendly, cheap and effective green growth promoters (Oudhia et al., 1998). The variation in the chemical composition of $O$. europaea cultivars may exhibit diverse allelopathic consequence on the germinated seeds (Khan et al., 2013).

Data of the growth bioassay experiment in the current study assure an increase in TSDW with all concentrations for the four cultivars, except TOF relative to control. On the other hand, TSL not exhibited a significant increase at all concentrations of the four cultivars except concentration $1.5 \%$. The concentration $1 \%$ of the four cultivars showed significant differences on the leaf area (LA) of $H$. vulgare.

An indirect relation between lower values of the different growth parameters and allelopathic inhibition may be the consequence of inhibition of water uptake (Tawaha and Turk, 2003) and alteration in the synthesis or activity of gibberellic acid (GA) (Olofsdotter, 2001). Additionally, allelochemicals inhibit germination and seedling growth probably by affecting cell division and elongation, processes that are very important at this stage, or by interfering with enzymes involved in the mobilization of nutrients necessary for germination (Batlang and Shushu, 2007). It is known that the presence of phenolic compounds inhibits the activity of gibberellic acid (Einhellig, 1996) or inhibit its synthesis which regulate de novo amylase production during seed germination (Chandler et al., 1984). Also, reduction may be due to different chemical compounds present in (OELCP) such as phenolics (Oleuropein, Catechin, Vanillic acid and Coumarin) flavonoid (Quercetin, Apigenin) reducing sugars and cardiac glycosides, these compounds have been reported to be active allelopathic chemicals 
dominant in $O$. europaea leaves affected on seed germination and growth (Vinson et al., 2005). Though, Gajam (2016) declared that recipient species are arranged in the order Raphanus sativus >Triticum aestivum >Vicia faba concerning the degree of sensitivity to Ficus carica leaf aqueous extract (FCLAE).

Several investigators (Fiorentino et al., 2003; Isidori et al., 2005) have reported the inhibition of plant and microbial growth by low-molecular-weight phenols present in olive leaves, oils and fruits, although highmolecular-weight polyphenols such as oleuropein has also shown toxic activity (Bisignano et al., 1999). Hydroxytyrosol has been identified as one of the major natural phenolics present in olive leaves (Fiorentino et al., 2003). However, many compounds remain unidentified and there is still controversy about the exact type and amounts of phytotoxic components in olive residues.

Oleuropein is the major phenolic composition of the olive leaf, oil, and fruit. Antioxidant capacity of oleuropein is $400 \%$ higher than vitamin C and twice of green tea or grape seed extract (Ozkaya and Ozkaya, 2011). Studies have indicated that oleuropein attenuates inflammatory response and improves histological and plasma markers of liver damage (Domitrovic et al., 2012).

Oleuropein is the major phenolic compound in olive leaves and fruits. In the present study, leaves attained values varies from 35 to $67 \mathrm{mg} / \mathrm{g}$ dry weight depending upon the cultivar. In addition to oleuropein, different compounds present also in olive leaves e.g. hydroxytyrosol, tyrosol, caffeic acid, verbascoside, rutin, luteolin 7-O-glucoside, luteolin 4-O-glucoside, apigenin-7-O-rutinoside and apigenin 7-O-glucoside. Hydrolysis of oleuropein yields elenolic acid glucoside and hydroxytyrosol (Le Toutour and Guedon, 1992).

Many compounds isolated from $O$. europaea fruits or leaves are thought to have been originated from Oleuropein via aglycon, by opening of olenolic acid ring with a final rearrangement into the secoiridoid compound such as hydroxytyrosol (Syed-Haris, 2010). Various processing and extraction methods were investigated to evaluate stability and recovery of oleuropein from olive leaves (Sawalha et al., 2009). However, several factors may influence the qualitative and quantitative phenolic composition of olive leaves among which we can cite date of collection (Brahmi et al., 2012) drying conditions (Silva et al., 2006) cultivation zone (Bilgin and Sahin, 2013) extraction procedure and cultivar (Rafiee et al., 2011).

In the present study cultivars; CHM, MAZ, PIC and TOF attained $35.02 \pm 1.59,47.24 \pm 2.05,55.42 \pm 1.41$ and $67.76 \pm 0.64 \mathrm{mg} / \mathrm{g}$ dry weight with the minimum record for $\mathrm{CHM}$ and maximum for TOF. The variation was highly correlated with the level of antioxidants activity of germinated $H$. vulgare. The antioxidant levels in $H$. vulgare seedlings were highly maximized as affected with Olea europaea crude powder for the first two cultivars (CHM and MAZ) relative to control. On contrarily, the two last cultivars (PIC and TOF) have nil effects on the antioxidant activities relative to control. Phytochemicals; the most bioactive food constituents are derived from plants. The large majorities of these phytochemicals are redox active molecules and therefore defined as antioxidants (Ammar et al., 2017). Antioxidants can eliminate free radicals and other reactive oxygen and nitrogen species, and these reactive species contribute to most chronic diseases (Lobo et al., 2010).

The juice of barley seedlings contains beta carotene, vitamins B1, B2, B6, B12, pantothenic acid, and folic acid as well as some minerals like potassium, calcium, iron, phosphorus, and magnesium. Other constituents are chlorophyll, amino acids, protein, fiber, and enzymes. Vitamin B12 deficiency may be avoided in vegetarian diets by supplementation with dehydrated barley seedling juice. Barley leaf extract has the ability to scavenge free radicals. Reactive oxygen species have been shown to play an important part in mediating the production of pro-inflammatory cytokines and can be instrumental in the pathogenesis of diseases such as rheumatoid, arthritis and gout. Animal data shows an increased production of oxygen-free radicals with barley leaf extract added to the diet. Clinical studies show blood levels of oxygen-free radicals were reduced by supplementation with $15 \mathrm{~g}$ /day barley leaf extract in patients with type 2 diabetes mellitus and hyperlipidemic patients. Young barley leaf extract is a good natural source of vitamins and minerals. It contains polyphenolic compounds and has been found to have antioxidant activity in a lipid peroxidation system (Benedet et al., 2007).

The present study can direct our awareness to the principle aim of barley cultivations and conclude that if barley is planting to be used in herbal medicine as antioxidant it prefers to be cultivated under $\mathrm{CHM}$ and MAZ olive trees and avoided to cultivate under the other two cultivars. This apex is therefore an essential conclusion to further elucidate the potential health effects of phytochemical antioxidants in diet.

In the present study, the potential of seedling storage protein (assess the genetic diversity) in Hordeum vulgare as affected by $0.5 \%$ and $2 \%$ of Olea europaea L. leaf crude powder (OELCP) for CHM, MZA, PIC and TOF cultivars was investigated. This technique is commonly used onto taxa that are phenotypically closely related (Galani et al., 2011), specifies as a beneficial method for discrimination of several genotypes (Agafonov et al., 2001) and characterization among cultivars (Dar et al., 2014).

A total of $10,9,13$ and 13 bands are produced subjected to CHM, MAZ, PIC and TOF crude powder respectively and five common bands at 9, 12, 44, 46 and $180 \mathrm{KDa}$ and two specific bands for MAZ cultivar at 10 and $77 \mathrm{KDa}$ and five specific bands for concentrations at 178 at $0.5 \%$ for CHM, $148,155 \mathrm{KDa}$ at 0.5 and $2 \%$ for MAZ and 29 and $177 \mathrm{KDa}$ at 0.5 and $2 \%$ for PIC. PIC cultivar (a cultivar attained high content of oleuropein) achieved the highest percentage of polymorphism of about $51 \%$ at both 0.5 and $2 \%$ OELCP. The minimum percentage of polymorphism achieved by MAZ cultivar (a cultivar attained low content of oleuropein)of about $32 \%$ at $0.5 \%$ and $36 \%$ at $2 \%$ of OELCP. Moreover, $\mathrm{CHM}$ cultivar caused high percentage of genomic 
template stability (GTS \%) in $H$. vulgare for all treatments (Control, 0.5 and 2\% OELCP) measuring about $100 \%, 86 \%$ and $82 \%$ respectively. TOF cultivar (high oleuropein content) achieved the lowest percentage of genomic template stability (GTS \%) in the two-affecting concentration in addition to control measuring about $100 \%, 36 \%$ and $32 \%$. Hegazy et al. (2007) reported that the seedling proteins decrease with the increase in the concentration of allelochemicals (oleuropein and other active constituents in the present study). This reduction may be due to the presence of phenolic compounds, which reduce the incorporation of phosphorus into DNA and RNA and also reduce the incorporation of certain amino acid into proteins and thus reduce the rate of protein synthesis. Also, this interference took place either by induction or repression of the protein bands. The relatively high frequency of disappearance of bands may reveal that the survival of the individuals was greatly affected by allelochemicals (Sunar et al., 2013). These allelochemicals could play an important role in inhibiting enzymes involved in these two processes accordance with Baziramakenga et al. (1997) who pointed out that the methionine incorporation into proteins was reduced by allelochemicals. Furthermore, it is notable the intensity of protein bands decreases or increase depended on type of allelechemicals found in Olea europaea L. leaf crude powder (OELCP), which affected on the recipient species (Yumnamcha et al., 2014).

\section{CONCLUSION}

The results of the current study are summarized in:

1. O. europaea leaves aqueous extract (OELAE) reduced germination percentage under high extract concentration while it promoted growth under low concentration levels.

2. The minimum level of oleuropein was recorded for CHM and maximum for TOF. The variation was highly correlated with the level of antioxidants activity of germinated $H$. vulgare grains.

3. Allelochemicals extracted from $O$. europaea significantly interfered with the protein expression of $H$. vulgareeither by induction or suppression.

4. CHM cultivar (low oleuropein content) caused high percentage of genomic template stability while TOF cultivar (high oleuropein content) achieved the lowest percentage of genomic template stability in $H$. vulgare for all treatments.

5. This study provides evidences on the differential allelopathic potential of $O$. europaea leaves. It has inhibitory and or stimulatory effects on growth $H$. vulgare. The effect differed with cultivar and extract concentration.

\section{REFERENCES}

AGAFONOV, A.V., O.A. STRUZHKINA, AND S. O. BATURIN. 2001. SDS-PAGE of endosperm proteins of individual seeds of Poa pratensis L. (Poaceae) in ecological and genetic studies. Sibirskii EkologicheskiiZhurnal, 1: 36-4.
ALGANDABY, M.M., E.T. EL-KENANY, AND S.M. EL-DARIER. 2014. Management of Chenopodium album L. through the allelopathic Effect of Mangifera indica L. Journal of Life Sciences, 3: 230-237.

AL-HUSSAINI, M.K. 2013. Improvement of Drought Tolerance of Vigna radiata L. R. Wilczek by Low Doses of Water Extract of Sorghum bicolor L. (Moench). M. Sc. Thesis Submitted to the Biology Department, College of Science, and University of Baghdad, Iraq. Pp.: 50.

AMMAR A., L. NAOUFAL, B. AZAM, G.W. DENNIS, AND A.L. DAVID (2017) Phytochemicals: Extraction, Isolation, and Identification of Bioactive Compounds from Plant Extracts. Plants, 6: 42.

BANDONIENE, D., M. MURKOVIC, W. PFANNHAUSER, P. VENSKUTONIS, AND D. GRUZDIENE. 2002. Detection and activity evaluation of radical scavenging compounds by using DPPH free radical and online HPLC-DPPH methods. European Food Research and Technology, 214:143-147.

BATLANG, U., AND D.D. SHUSHU. 2007. Allelopathic activity of sunflower (Helianthus annuus L.) on growth and nodulation of Bambara groundnut (Vigna subterranean L.) Verdc. Journal Agronomy, 4: 541-547.

BAZIRAMAKENGA, R.; G. LEROUX, R. SIMARD, AND P. NADEAU. 1997. Allelopathic effects of phenolic acids on nucleic acids and protein levels in soybean seedlings. Canadian Journal of Botany, 75: 445-450.

BENEDET J.A., H. UMEDA, AND T. SHIBAMOTO. 2007. Antioxidant activity of flavonoids isolated from young green barley leaves toward biological lipid samples. J. Agricultural and Food Chemistry. 55:5499-504.

BILGIN M., S. ŞAHIN. Effects of geographical origin and extraction methods on total phenolic yield of olive tree (Olea europaea) leaves. J Taiwan Inst Chem Eng. 2013;44:8-12. doi: 10.1016/j.jtice. 2012. 08.008

BISIGNANO, G., A. TOMAINO, R.LO CASCIO, G. CRISAFI, N. UCCELLA, AND A. SAIJA. 1999. On the in vitro antimicrobial activity of oleuropein and hydroxytyrosol. Journal of Pharmacy and Pharmacology, 51:971-4.

BOLIGON, A., AND M. ATHAYDE. 2014. Importance of HPLC of plants extracts. Austin Chromatography, Mini Review, 3:1-2.

BRAHMI, F., B. MECHRI, S. DABBOU, M. DHIBI, AND M. HAMMAMI. 2012. The efficacy of phenolics compounds with different polarities as antioxidants from olive leaves depending on seasonal variations. Industrial Crops and Products, 38: 146-152.

CAIN AND CASTRO. 1959. Manual of Vegetative Analysis.Harper, New York.

CHANDLER, P.M., J.A. ZUCAR, J.V. JACOBSON, T.J.V. HIGGINS, AND A.S. INGLIS. 1984. The effect of gibberellic acid and abscisic acid on a-amylase mRNA levels in barley aleurone layers studies using an amylase cDNA clone. Plant Molecular Biology, 3: 407-408. 
CHEEMA, Z., M. FAROOQ, AND ABDUL WAHID. 2013. Allelopathy: Current Trends and Futur Application. Springer Verlag, Berlin, Heidelberg, pp. 520.

CIMINO, M.C. 2006. Comparative overview of current international strategies and guidelines for genetic toxicology testing for regulatory purposes. Environmental and Molecular Mutagenesis Journal, 7: 362390.

DAR, A.A., A.R. CHOUDHURY, AND N.A. ARUMUGAM. 2014. .A study on seed protein profile of Indian cultivars of Sesamum indicum L. International Journal of Biotechnology, 2(6): 10-17.

DOMITROVIC, R., H. JAKOVAC, V.V. MARCHESI, I. SAIN, Z. ROMIC, AND D. RAHELIC. 2012. Prevention and therapeutic effects of oleuropein against carbon tetrachloride-induced liver damage in mice. Pharmacological Research, 65(4):451-64.

DUKE, S.O. 2010. Allelopathy: Current status of research and future of the discipline: A Commentary. Allelopathy Journal, 25 (1): 17-30.

EINHELLIG, F.A. 1996. Mechanism of action of allelochemicals in Allelopathy. Agronomy Journal, 88: 886-8.

EL-DARIER, S.M., R.I. MARZOUK, S.A. KAMAL, AND I.H. NOUR. 2018. (Under publication) Allelopathy as a biochemical marker: allelopathic effect of the Egyptian Marrubium L. Species extracts on seeds germination and seedling growth of Raphanus sativus $\mathrm{L}$.

EL-ROKIEK, G.K., R.R. EL-MASRY, K.N. MESSIHA, AND S.A. AHMED. 2010. Allelopathic effect of mango Leaves on the growth and propagative capacity of purple nutsedge (Cyperus rotundus L.). Journal of American Science, 9: 151-159.

FIORENTINO, A., A. GENTILI, M. ISIDORI, P. MONACO, A. NARDELLI, A. PARRELLA, AND F. TEMUSSI. 2003. Environmental effects caused by olive mill wastewaters: toxicity comparison of low-molecular-weight phenol components. Journal of Agricultural and Food Chemistry, 51:1005-9.

GAJAM, K.I.M. 2016. Allelopathic Interaction among Ficus carica L. (Moraceae) and some Cultivated Intercrops. M.Sc. Botany and Microbiology Department, Faculty of Science, Alexandria University, pp: 95.

GALANI, S., F. NAV, F. SOOMRO, I. JAMIL, ZIAUL-HASSAN, A. AZHAR, AND A. ASHRAF. 2011. Seed storage protein polymorphism in ten elite rice (Oryza sativa L.) genotypes of Sindh. African Journal of Biotechnology, 10(7): 1106-1111.

HARBORNE, J.B. 1998. Phytochemical Methods: A Guide to Modern Techniques of Plants Analysis. Pp. 54-84. 2nd ed. London: Chapman and Hall.

HEGAZY, A. K., S.K. GODA, AND H.F. FARRAG. 2007. Protein Expressions of Some Cultivated and Weed Plants in Response to Invasive Plant Mulching. Global Journal of Molecular Sciences, 2(1), 01-07.

INSKEEP, W.P., AND P.R. BLOOM. 1985. Extinction coefficients of chlorophylla and B in N,N-dimethyl- formamide and $80 \%$ acetone. Plant Physiology, 77:483-485.

ISIDORI, M., M. LOVORGNA, A. NARDELLI, AND A. PARRELLA. 2005. Model study on the effect of 15 phenolic olive mill wastewater constituents on seed germination and Vibrio fischeri metabolism. Journal of Agricultural and Food Chemistry, 53: 8414-7.

KHAN, M.S., M.A. ISLAM, AND H.K. NOGUCHI. 2013. Evaluation of allelopathic activity of three mango (Mangifera indica) cultivars. Asian Journal of Plant Sciences, 6-8: 252-261.

KIM, D., O. CHUN, Y. KIM, H. MOON, AND C. LEE. 2003. Quantification of phenolics and their antioxidant capacity in fresh plums. Journal of Agricultural and Food Chemistry, 51: 6509-6515.

KIRKPATRICK, L.A., AND B.C. FEENEY. 2013. A simple guide to IBM SPSS statistics for version 20.0. Student ed. Belmont, Calif.: Wadsworth, Cengage Learning.

LAEMMLI, U.K. 1970. Cleavage of structural proteins during the assembly of bacteriophage T4.Nature Publishing Group, 277: 680-684.

LAMBERS H., F.S.III. CHAPIN, AND T.L. PONS. (1998). Plant Physiological Ecology. New York: Springer.

LE TOUTOUR, B., AND D. GUEDON. 1992. Antioxidative activities of Olea europaea leaves and related phenolic compounds, Phytochemistry, 31: 1173-1178.

LICHTENTHALER, H.K. 1987. Chlorophylls and carotenoids: Pigments of photosynthetic Biomembranes. Methods in Enzymology, 148: 350-382.

LOBO V., A. PATIL, A. PHATAK, AND N. CHANDRA. 2010. Free radicals, antioxidants and functional foods: Impact on human health. Pharmacognosy Review, 4(8): 118-126.

MARINOVA, D., F. RIBAROVA, AND M. ATANASSOVA. 2005. Total phenolics and total flavonoids in Bulgarian fruits and vegetables. Journal of the University of Chemical Technology and Metallurgy, 40: 255-260.

MARZOUK, R.I., S.M. EL-DARIER, M. MABROUK, AND K. KHATTAB. 2017. Growth and Molecular Expression of Okra Seeds Interacted with Fourteen Mango Cultivars in Mixed Cropping System. Journal of Agricultural Science; Published by Canadian Center of Science and Education, Vol. 9, No. 8.

MOHAMED, M.E., AND I. SAAD EL DIN. 2002. Olive Cultivation and Production. Horticulture Research Institute, Bulletin No. 720.

NIAKAN, M., M. TAJARI, AND M. GHORBANLI. 2008. Effects of salinity on allelopathic potential of canola (Brassica napusL.).Allelopathy Journal, 21: 329-338.

OLOFSDOTTER, M. 2001. Rice-A Step toward Use of Allelopathy.Agronomy Journal, 93: 3-8.

OUDHIA, P., S.S. KOLHE, AND R.S. TRIPATHI. 1998. Naz and Bano Page 39 Allelopathic effect of Blumea lacera L. on rice and common Kharif weeds Oryza, 35: 175-177. 
OZKAYA F.D., AND M.T. OZKAYA. 2011. Oleuropein using as an Additive for Feed and Products used for Humans. Journal of Food Processing and Technology, 2: 113.

RAFIEE, Z., S.M. JAFARI, M. ALAMI, AND M. KHOMEIRI. 2011. Microwave-assisted extraction of phenolic compounds from olive leaves; a comparison with maceration. Journal of Animal and Plant Sciences, 21: 738-745.

REIGOSA, J., N. PEDROL AND I. GONZÁLEZ. 2006. Allelopathy: A Physiological Process with Ecological Implications. Springer, pp: 639.

RICE, E.L. 1984. Allelopathy, 2nd Edn., Academic Press, New York. 422p.

SAWALHA, S., D. ARRAEZ-ROMAN, A. SERGURA CARRETERO, AND A. FERNANDEZGTIERREZ. 2009. Characterization of Phenolic Compounds in Diatomaceous Earth Used in the Filtration Process of Olive Oil by HPLC-ES-TOF (MS).Agro Food Industry Hi-Tech, Food technologies, 20: 46-50.

SILVA S., L. GOMES, F. LEITÃO, A.V. COELHO, L. V. BOAS. 2006. Phenolic compounds and antioxidant activity of Olea europaea $\mathrm{L}$. fruits and leaves. Food Science and Technology International, 12(5): 385-396.

SINGLETON, V.L., R. ORTHOFER, AND R.M. LAMUELA-RAVENTOS. 1999. Analysis of total phenols and other oxidation substrates and antioxidants by means of Folin-Ciocalteu reagent. In: Oxidants and Antioxidants, Method Enzymology, vol. 299, pp. 152-178.

STAMP, NANCY. 2003. "Out of the quagmire of plant defense hypotheses", The Quarterly Review of Biology, 78 (1): 23-55, Stamp, Nancy (March 2003),
"Out of the quagmire of plant defense hypotheses", The Quarterly Review of Biology, 78 (1): 23-55.

SUNAR, S., N. YILDIRIM, O. AKSAKA, AND G. AGAR. 2013. Determination of the genotoxic effects of Convolvulus arvensis extracts on corn (Zea mays L.) seeds. Toxicology and Industrial Health, 29(5): 449-459.

SYED-HARIS, O. 2010. Oleuropein in Olive and Its Phamacological Effects. Scientia Pharmaceutica, 78: 133-154.

TANG, C.S., K. KOMAI AND R.S. HUANG. 1989. Phytochernical Ecology. In: Allelochemicals, Mycotoxins and Insect Pheromones and Ailomones, Chou, C.H. and G.R. Waller (Eds.). Institute of Botany, Taipei, pp: 217-226.

TAWAHA, A.M., AND M.A. TURK, 2003. Allelopathic effects of black mustard (Brassica nigra) on germination and growth of wild barley (Hordeum spontaneum). Journal of Agronomy and Crop Sciences, 189: 298-303.

VINSON, J. A., L. ZUBIK, P. BOSE, N. SAMMAN, AND J. PROCH. 2005. Dried fruits: excellent in vitro and in vivo antioxidants. Journal of the American College of Nutrition, 1: 44-50.

YUMNAMCHA, T., U. NONGTHOMBA,. AND M.D. DEVI. 2014. Phytochemical screening and evaluation of genotoxicity and acute toxicity of aqueous extract of Croton tiglium L. International Journal of Scientific and Research Publications, 4(1), 1-5.

ZHENG Y.L., Y.L. FENG, L.K. ZHANG, R.M. CALLAWAY, A. VALIENTE-BANUET AND D. Q. LUO. 2015. Integrating novel chemical weapons and evolutionarily increased competitive ability in success of a tropical invader. New Phytologist. 205: 1350-1359. 


\title{
الاستجابات المختلفة لنبات الثعير للمركبات الأليلوكيميائية لبعض أصناف الزيتون
}

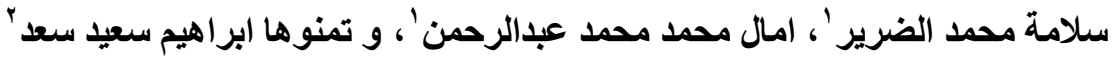

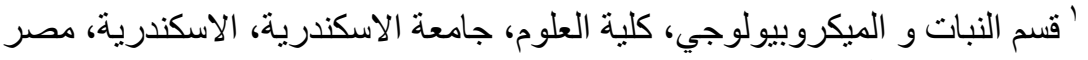

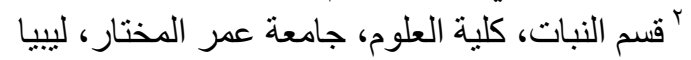

\section{الملذص العربي}

تهدف هذه الدراسة الي التعرف علي تأثثر النشاط البيولوجي للمستخلصات المائية و المسحوق الخام لأوراق أربعة اصناف من اشجار الزيتون (شملال، مانزونيلا، بيكوال و التفاحي) علي بعض معاملات الانبات و النمو و بعض القياسات الفسيولوجية و

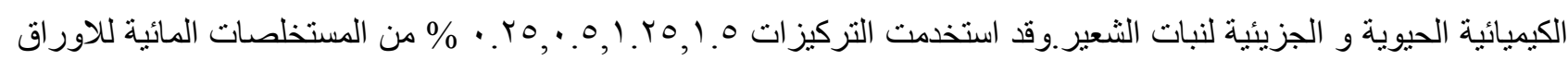
و التركيزات ه. • و ؟r\% بالنسبة للمسحوق الجاف بالإضافة إلي العينة الضابطة. و اثثتت الدراسة ان التناثير المثبط قد اختلف مع العامل المقاس والصنف وكذلك تركيز المستخلص المستخدم في حين انه قد في

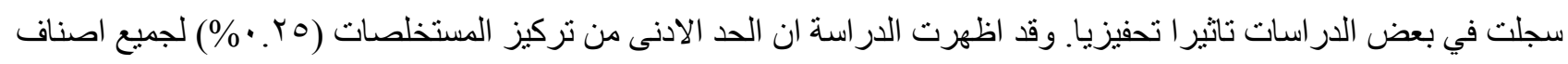

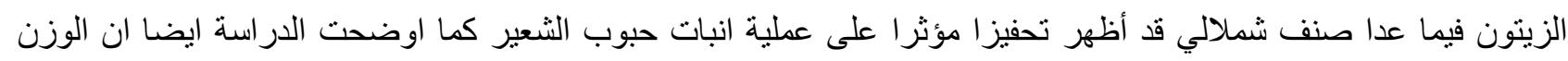
الكلي الجاف للبادرات قد زاد مع كل التركيزات المستخدمة من الاور اق لاصناف الزيتون فيما عدا صنف التفاحي. أما بالنسبة لاصباغ البناء الضوئي فقد تبين من الدراسة ان تركيز كلوروفيل أ في أوراق الثعير قد زاد بشكل ملحوظ مع تركيز المسحوق الخام من اوراق اصناف الزيتون باستثناء صنف تفاحي. اما بالنسبة لكلوروفيل ب و الكاروتين فقد اظهر ا اضطر ابا في تئي تركيز هما، زيادة و نقصان، مع تركيز ات المسحوق الخام من الاصناف الاربعة للزيتون. وقد تبين من الدراسة أيضا ان مركب الاوليوروبين وهو مركب فينولي رئيسي في اور اق وزيت وثمرة الزيتون قد بلغت فئن فيمته من 0ب الى لاT ملجم/جر ام وزن جاف اعتمادا على الصنف ،حيث كان اقصى تركيز في صنف التفاحي و اقل تركيز في صنف

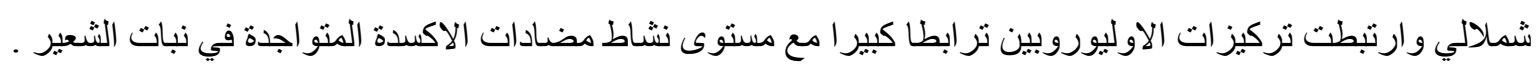
وقد وجد ان صنف شملالي المحتوي على نسبة منخفضة من الاليوروبين تسبب في زيادة نسبة استقرار القالب الجينومي في

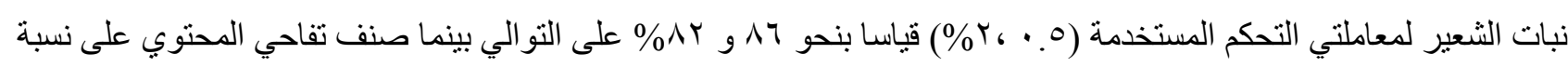

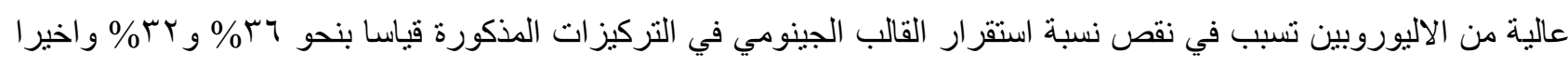
يمكن ان نستنتج انه اذا كانت زراعة الشعير لاغر اض استخدامه كدواء عشبي وكمضاد للاكسدة فانه يفضل زر اعته تحت اشجار الزينون صنف شملالي ومانزونيلا ونتجنب زر اعته تحت اشجار الزيتون للصنفين الاخرين وهما التفاحي وبيكو ال. 